\title{
STANDAR HUKUM INTERNASIONAL PENYELENGGARA PEMILIHAN UMUM, DAN PENGARUHNYA TERHADAP HUKUM NEGARA INDONESIA
}

\author{
Patawari \\ Universitas Indonesia Timur
}

\begin{abstract}
Abstrak
Beberapa standar hukum Internasional tentang penyelenggara pemilihan umum, sebagai dasar di dalam menentukan dasar hukum nasional penyelenggara pemilihan umum di Indonesia yang dituangkan dalam peraturan nasional. Sehingga penulisan ini perlu untuk mengetahui seberapa besar pengaruhnya ketentuan hukum internasional terhadap ketentuan hukum nasional Indonesia mengenai penyelenggara pemilihan umum. Penulisan ini menganalisa beberapa literature, standar hukum intensional, konstitusi dan peraturan hukum nasional Indonesia kaitannya dengan penyelenggara pemilihan umum. Standar hukum internasional menghendaki adanya peraturan hukum penyelenggara pemilihan umum yang dapat mewujudkan demokrasi dengan mengedepankan adanya kesetararaan individu. Hal tersebut tidak memiliki pengaruh kuat terhadap ketentuan hukum penyelenggara pemilihan umum di Indonesia sebab mengacu pada konstitusi dengan ketentuan kualitas penyelenggara yang professional, integritas, akuntabilitas, dan kredibiltas, dengan asas jurdil dan luber. Seharusnya unsur unsur professional, integritas, akuntabilitas, dan kredibilitas, diatur dalam ketentuan peraturan penyelenggara pemilihan umum.
\end{abstract}

Kata Kunci: Hukum Internasional, Standar Hukum, Pemilu

\section{PENDAHULUAN}

Penyelenggara pemilihan

umum menjadi bagian penting di dalam mewujudkan demokratisasi yang konstitusional, sebagaimana landasan konstitusional Indonesia sebagaimana pada sila ke-IV UUD NRI 1945 bahwa ".......Kerakyatan yang dipimpin oleh hikmat kebijaksanaan dalam permusyawaratan/perwakilan......." Pada sila tersebut menjadi dasar dalam melaksanakan demokrasi di Indonesia. Pemahaman dasar demokrasi memang dikenal adanya pemilihan umum secara langsung dan pemilihan umum secara tidak langsung. Sehingga, Di dalam pelaksanaan pemilihan umum diperlukan adanya penyeleggara pemilihan umum yang bekerja secara independen yang mekanismenya dapat dipertanggungjawabkan secara hukum (berdasarkan hukum), dan dapat dipercayai oleh masyarakat.

Sebagai turunan dalam Pembukaan UUD NRI 1945 sekaitan dengan adanya kedaulatan tertinggi ada ditangan rakyat dan dilaksankaan secara bijaksana dan dalam permusyawaratan, maka sebagaimana diatur pada Pasal 22E Ayat (1) UUD NRI 1945 bahwa "Pemilihan umum dilaksanakan secara langsung, umum, bebas, rahasia, jujur, dan adil setiap lima tahun sekali." Guna dapat mewujudkan asas pemilihan pemilihan umum yang langsung, umum, bebas, rahasia, jujur dan adil maka tentunya perlukan penyelenggara pemilihan umum 
yang bekerja secara professional, integritas, transparan, dan akutabilitas.

Konstitusi mengamanatkan adanya pemilihan umum yang diselenggarakan oleh suatu komisi pemilihan umum yang bersifat, nasional, tetap dan , mandiri. Dari hal tersebut sehingga lahir suatu lembaga sebagai penyelenggara pemilihan umum yakni adalah Komisi Pemilihan Umum atau disingkat dengan KPU, lembaga KPU merupakan lembaga yang memiliki fungsi pembantuan, penunjang atau sebagai organ penunjang bukan sebagai fungsi utama.

Disisi lain, sistem hukum pemilihan umum, harus mengakomodir sistem penyelenggaraan pemilihan umum yang paripurna. Dengan adanya sistem hukum pemilihan umum dan penyelenggara yang professional, maka dapat di partikan keberhasilan penyelenggaraan pemilu. Sebaliknya bawah sistem hukum pemilihan umum yang tidak baik dan penyelenggara yang tidak professional maka dapat dipastikan pemilihan umum tidak mendapatakan legitimasi kepercayaan masyarakat terhadap.

Sekaitan dengan adanya lembaga yang bekerja sebagaimana layaknya tugas pemerintahan hal tersebut seiring dengan pandangan oleh Muchlis Hamdi.

"hampir semua negara memiliki lembaga yang dapat disebut sebagai "auxiliary state's bodies". Menurutnya, lembaga ini umumnya berfungsi untuk mendukung lembaga negara utama. Auxiliary state`s organ dapat dibentuk dari fungsi lembaga negara utama yang secara teori menjalankan tiga fungsi, yakni legislatif, eksekutif, dan yudikatif. Pembentukan organisasi pendukung ini, dalam rangka efektivitas pelaksanaan kekuasaan yang menjadi tanggung jawabnya. Selain itu, juga terdapat lembaga independen, yang kewenangannya dapat bersumber dari arahan konstitusi negara atau kebutuhan penyelenggaraan pemerintahan dan umumnya dibentuk berdasarkan undangundang."

Komisi pemilihan umum kaitannya dengan auxiliary state's bodies atau Auxiliary state's organ. Bahwa eksistensi lembaga komisi pemilihan umum terlahir dari amanah konstitusi (UUD 1945) dalam rangka menyelenggarakan pemilihan umum. Maka komisi pemilihan merupakan bagian dari struktur ketatanegaraan. Dengan dasar bahwa:

1. Eksistensi komisi pemilihan umum adalah melakukan tugas pembantuan terhadap bagian dari fungsi-fungsi kekuasaan negara. baik fungsi legislatif, ekekutif maupun fungsi yudikatif.

2. Sifat kekuasaan yang dapat dimiliki komisi pemilihan umum bentuk quasi atau semi pemerintahan dengan fungsi tunggal (Pengatur). Terhadap fungsi terhadap organ penunjang bukan hanya diberikan satu fungsi namun demikian dapat saja ia diberikan fungsi campuran sebagai; pengatur, pelaksanan dan sebagai penghukum.

3. Bahwa komisi pemilihan umum sebagai lembaga yang bersifat permanen, dapat juga 


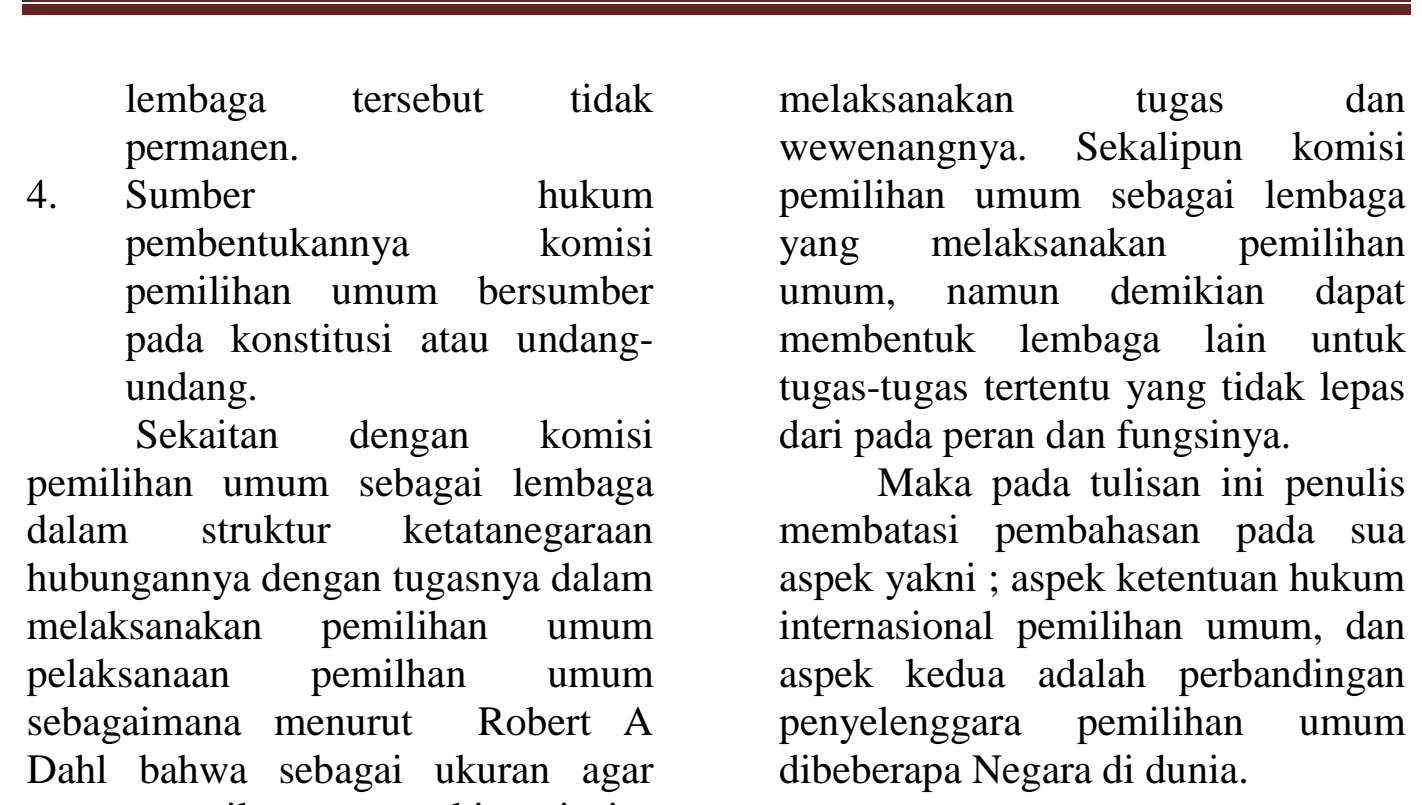
suatu pemilu memenuhi prinsipprinsip demokrasi:

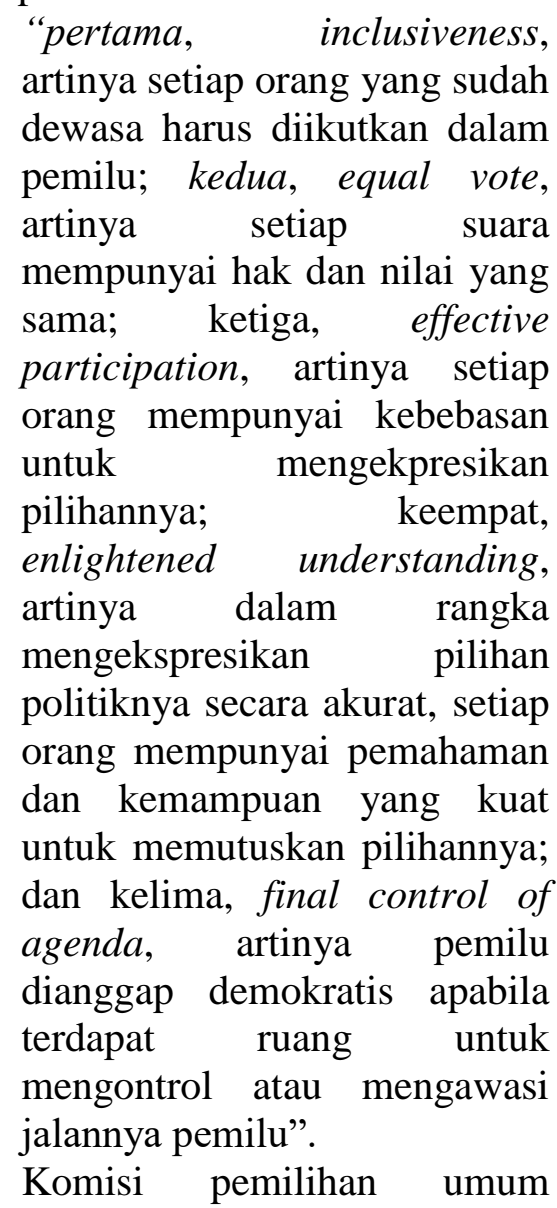
sebagai lembaga yang melaksankan final control of agenda (mengongtrol atau mengawasi jalannya pemilihan umum), sekaitan dengan amanah dalam konstitusi maka komisi pemilihan umum adalah sebagai lembaga yang berdiri sendiri dalam 
mendiskusikan dan

menentukan pilihannya; e)

adanya keleluasaan bagi

peserta pemilu untuk

berkompetisi secara sehat; f)

adanya penghitungan suara

yang dilakukan secara jujur; g)

adanya netralitas birokrasi;

dan, h) adanya lembaga penyelenggara pemilihan yang independen.

Sekaitan

dengan

pandangan Taylor, mengenai

pemilihan umum dan

demokrasi, juga di kemukakan

oleh Didik Sukriono bahwa:

"Pemilu sebagai arena

kompetisi dalam

menyeleksi partai politik

peserta pemilu,

efektifitasnya sangat

tergantung dari: Pertama,

aturan main atau sistem

kompetisinya dalam hal

ini sistem pemilu yang

diterapkan; Kedua,

jumlah dan informasi

obyektif tentang kinerja

partai politik sebagai

peserta pemilu; Ketiga,

tingkat kedewasaan

rakyat yang memilih;

Keempat, kredibilitas

komisi pemilihan umum

sebagai penyelenggara

pemilihan umum."

Beberapa pandangan di atas, memberikan gambaran adanya penyelenggaraan pemilihan umum mulai dari proses rekrutemen orang orang yang hendak menjadi wakil dari rakyat, adanya pengaturan hukum yang mampu mengakomodir segala bentuk aktifitas penyelenggaraan pemilhan umum, dan adanya penyelenggara yang idenpenden, transparan, dan professional.

Pada pembahasan ini akan menguraikan standar hukum internasional penyelenggara pemilihan umum, dan perbandingan penyelenggara pemilihan umum dibeberapa Negara, sebagaimana diuraikan berikut di bawah ini.

\section{B. Standar}

Hukum

Internasional

Standar pemilihan umum yang demokratis Internasional bahwa penentu demokratis-tidaknya suatu pemilihan umum adalah adanya badan atau lembaga penyelenggara Pemilu. Lembaga penyelenggara Pemilu harus melakukan semua kegiatan pemilihan umum secara independen, transparan, dan tidak berpihak. Dalam menjalankan fungsinya lembaga itu harus taat asas, terukur dan berpijak pada peraturan. Lembaga penyelenggara Pemilu harus mengedepankan

profesionalisme, bekerja efektif dan efesien, dan mengambil keputusan cepat dan tepat. Kredibilitas lembaga penyelenggara Pemilu ditentukan oleh keyakinan publik atas apa yang mereka kerjakan sejak tahap pertama Pemilu (pendaftaran pemilih) hingga tahap akhir (pelantikan calon terpilih).

IDEA (Institute for Democracy and Electoral Assistance) merumuskan sejumlah standar internasional yang bisa menjadi tolok ukur demokratis tidaknya suatu 
pemilihan umum. Standar internasional ini merupakan syarat minimal bagi kerangka hukum atau undang-undang untuk menjamin pemilihan umum yang demokratis.

Adapun sumber utama standar internasional pemilihan umum demokratis itu adalah berbagai deklarasi dan konvensi internasional maupun regional, seperti Deklarasi Universal Hak Asasi Manusia 1948, Perjanjian Internasional tentang Hak-hak Sipil dan Politik 1960, Konvensi Eropa 1950 untuk Perlindungan Hak Asasi Manusia dan Kebebasan Asasi, juga Piagam Afrika 1981 tentang Hak Manusia dan Masyarakat.

Berdasarkan dokumendokumen tersebut, dirumuskan 15 aspek pemilu demokratis, yaitu:

a) penyusunan kerangka hukum;

b) pemilihan sistem pemilu;

c) penetapan daerah pemilihan;

d) hak untuk memilih dan dipilih;

e) pendaftaran pemilih dan daftar pemilih;

f) akses kertas suara bagi partai politik dan kandidat;

g) kampanye pemilu yang demokratis;

h) akses ke media dan kebebasan berekspresi;

i) pembiayaan dan pengeluaran;

j) pemungutan suara;

k) penghitungan dan rekapitulasi suara;

1) peranan wakil partai dan kandidat;

m) pemantauan pemilu; n) kepatuhan terhadap hukum;

o) penegakan peraturan pemilu; dan

p) lembaga penyelenggara pemilu.

Khusus tentang lembaga penyelenggara pemilu, standar internasional pemilihan umum demokratis menegaskan perlu adanya jaminan hukum, bahwa lembaga tersebut bisa bekerja independen. Independensi penyelenggara pemilu merupakan persoalan penting, karena mesin-mesin penyelenggara pemilu membuat dan melaksanakan keputusan yang dapat mempengaruhi hasil pemilu.

Berdasarkan hal di atas, maka lembaga penyelenggara pemilihan umum bekerja dalam kerangka waktu yang cukup (efesien), memiliki sumberdaya yang mumpuni, dan tersedia dana yang memadai. Undang-undang pemilihan umum harus mengatur ukuran, komposisi, dan masa kerja anggota lembaga penyelenggara pemilu. Juga mengatur hubungan antara lembaga penyelenggara pemilu pusat dan lembaga-lembaga pemilu tingkat yang lebih rendah, serta hubungan antara semua lembaga pemilu dengan lembaga eksekutif. Undangundang harus membuat ketentuan tentang mekanisme untuk memproses, memutuskan, dan menangani keluhan dalam pemilihan umum secara tepat waktu.

$$
\text { Beberapa standar }
$$

hukum internasional sebagai bagian peting terhadap dasar - 
dasar untuk penyelenggara pemilihan umum dibeberapa negara. Dengan melakukan perubahan / penyesuaian perundang undangan nasional. bahwa berdasarkan pada standar hukum internasional untuk penyelenggara pemilihan umum, yaitu :

Pertama, sebagaimana pada Pasal 21 ayat 1 Deklarasi Dunia tentang Hak Asasi Manusia tahun 1948 bahwa;

"Setiap orang berhak untuk berperan serta dalam pemerintahan di negaranya, baik secara langsung maupun melalui perwakilan yang dipilih secara bebas".

Penekanan pada Pasal tersebut adalah adanya hak disetiap warganegara untuk berpartisipasi di dalam penyelenggaraan urusan negara masing-masing. makna berperan serta bukan hanya pada ranah keterwakilan dalam parlemen namun demikian juga termasih dalam eksekutif, legislatif, dan yudikatif, yang penyelenggaraannya

dilaksanakan baik secara langsung maupun tidak langsung. Baik pemilihan atau penunjukan.

Kedua, Pasal 3 Konvensi tentang Hak-hak Politik Wanita tahun 1952 bahwa:

"Wanita berhak untuk memegang jabatan publik dan melaksanakan semua fungsi-fungsi publik, yang ditetapkan oleh undang-undang nasional, dengan ketentuan yang setara dengan pria, tanpa adanya diskriminasi."
Berdasar pada Konvensi tentang Hak-hak politik wanita adalah penekananya pada tidak adanya diskriminasi terhadap perempuan dan laki laki untuk terlibat langsung atau tidak langsung dalam urusan kenegaraan.

Ketiga, Konvensi tentang Penghapusan Semua Bentuk Diskriminasi Terhadap Wanita tahun 1979 Pasal 7 bahwa

"Negara-negara Peserta harus mengambil semua langkah-langkah yang layak untuk menghapuskan

diskriminasi terhadap wanita dalam kehidupan politik dan publik di negara yang bersangkutan dan, khususnya, harus memastikan, dengan ketentuan yang setara dengan pria, hak-hak: (b) Untuk berperanserta dalam perumusan kebijakan pemerintah dan pelaksanaannya dan untuk memegang jabatan publik dan melaksanakan semua fungsi-fungsi publik pada setiap tingkatan pemerintahan; (c) Untuk berperan serta dalam lembaga-lembaga swadaya masyarakat dan perhimpunan-

perhimpunan yang mengurusi kehidupan masyarakat dan politik di negara yang bersangkutan"

Keempat, Berbagai dokumen PBB (Laporanlaporan Sekjen, resolusiresolusi Sidang Umum, resolusi-resolusi ECOSOC, 
laporan-laporan dalam Komite HAM dll.) Sidang Umum PBB, A/RES/46/137 tanggal 17 Desember 1991 tentang Peningkatan Keefektifan Prinsip Pemilu Berkala dan Murni pada siding umum umum di tegaskan bahwa : "...Menegaskan kembali Deklarasi Universal tentang Hak Asasi Manusia, yang menetapkan bahwa setiap orang berhak untuk berperanserta dalam pemerintahan di negaranya, baik secara langsung maupun melalui perwakilan yang dipilih secara bebas, bahwa setiap orang berhak atas akses yang sama kepada layanan publik di negaranya, bahwa Kehendak rakyat merupakan dasar dari kewenangan pemerintah; kehendak tersebut harus dinyatakan di dalam pemilu berkala dan murni yang harus dilaksanakan dengan hak pilih yang sama dan setara dan harus dilaksanakan dengan surat suara rahasia atau dengan prosedur pemungutan suara bebas yang setara."

Kelima, Pasal 20 Deklarasi Hak dan Kewajiban Manusia American Tahun 1948 bahwa:

"Hak untuk Memilih dan keikutsertaan dalam Pemerintah, Setiap orang yang memiliki kapasitas hukum berhak untuk ikut serta dalam pemeritah negaranya, baik secara langung atau melalui perwakilannya, dan untuk ambil bagian dalam pemilihan umum, yang akan dilaksanakan melalui surat suara rahasia, dan secara jujur, berkala dan bebas."

Keenam. Instrument Konvensi Hak Asasi Manusia Amerika Tahun 1969. Pada Pasal 23 ayat 1 Hak untuk Ikut serta dalam Pemerintah, bahwa:

"Setiap warga negara berhak atas hak-hak dan kesempatan sebagai berikut: a. Untuk ikut serta dalam melaksanakan urusan publik, secara langsung atau tidak langsung atau melalui perwakilan yang dipilih secara bebas;"

Ketujuah, Pasal 13 ayat 1 Piagam Afrika (Banjul) tentang hak-hak manusia dan masyarakat Tahun 1981.bahwa :

"Setiap warga negara berhak untuk secara bebas ikut serta dalam pemerintah negaranya, baik secara langsung atau tidak langsung atau melalui perwakilan yang dipilih secara bebas sesuai dengan ketentuan hukum."

Kedelapan, Deklarasi Parlemen Internasional Tentang Kriteria untuk Pemilihan yang Bebas dan Adil Tahun 1994 Majelis Parlemen Internasional, Menegaskan kembali $\begin{array}{ll}\text { “... Dengan } & \text { demikian } \\ \text { mengadopsi } & \text { Deklarasi }\end{array}$ 
tentang Pemilihn yang Bebas dan Adil sebagai berikut, dan menganjurkan

Pemerintahanpemerintahan dan Parlemen-parlemen di seluruh dunia untuk menganut pedoman Prinsip-prinsip dan Standar-standar yang ditentukan di dalamnya: pada pasal 3 ayat (1) bahwa Setiap orang berhak untuk ikut serta dalam pemerintah negara mereka dan harus memiliki kesempatan yang sama untuk menjadi calon dalam pemilihan. Kriteria untuk keikutsertaan dalam pemerintah ditentukan sesuai dengan undangundang dasar nasional dan hukum dan tidak boleh bertentangan dengan kewajiban internasional Negara."

Dari beberapa standar internasional sebagai dasar pertimbangan terhadap masyarakat atau warganegara untuk berpartisipasi sebagai penyelenggara pemilihan umum, dapat ditarik kesumpulan bahwa;

1. Adanya hak setiap warganegara atau masyarakat untuk terlibat dalam urusan pemerintahan yang dipiliha secara langsung atau tidak langsung.

2. dalam urusan pemerintahan tidak ada diskriminasi antara wanita dan pria. Kesmuanya memiliki hak untuk berpartisipasi dalam urusan pemerintahan.

3. penyelenggaraan pemerintahan adalah menajdi kehendak dari pada masyarakat /warganegara. Dari hal tersebut dehingga pennyelengaraan negara adalah harus berdasarkan pada kehendak masyarakat. terhadap penyelenggara pemilihan umum, maka mereka yang terlibat dan aturanyang mengaturnya adalah harsu berdasar pada kehendak dan keinginan masyarakat /warganegara.

4. Warganegara yang berhak ikut di dalam urusan pemerintahan adalah mereka yang memiliki kapastitas.

5. kriteria di lakukan di atur dalam perundang undangnan nasional masing-masing negara.

Jika mengacu pada 8 (delapan) standar hukum internasional terhadap penyelenggara pemilihan umum, tidak begitu lengkap sebab tidak menjawab persoalan kapasitas warganegara yang dapat menjadi penyelenggara pemilihan umum. Kecuali, Deklarasi Hak dan Kewajiban Manusia American Tahun 1948 yang mengatur adanya kapasitas orang dalam urusan publik. seharusnya beberapa standar hukum internasional menerapkan suatu nilai atau kompetensi /kapasitas warganegara yang dapat menjadi bagian dalam urusan publik termasuk 
penyelenggaraan pemilihan umum. Sebab jika hanya menekankan pada standar hukum bahwa semua orang berhak. Maka, tentunya tidaklah begitu penting untuk diatur sebab memang disetiap negara demokrasi mengendaki adanya keterlibatan /partisipasi warganegara dalam urusan kenegaraan baik langsung maupun tidak langsung.

Di setiap negara, sebagai bentuk kedaulatan adalah seharusnya berdasar pada konstitusi masing-masing. Dasar hukum internasional hanya sebagai dasar kesamaan suatu edeologi yang termaktub didalam konstitusi negara masing-masing. sebab konstitusi negara merupaka batasan dari suatu pemerintahan negara untuk berbuat atau tidak berbuat.

Terkait dengan komisi pemilihan umum, sebagai lembaga penyelenggara pemilihan umum hubungannya dengan standar hukum internasional beberapa point penting untuk dapat di jadikan dasar nilai adalah; semua warganegera berhak untuk berperan serta sebagai penyelengara namun adalah mereka yang mempunyai kapasitas. Artinya bawah di berbagai lembaga tidak pada satu individu tidak sepenuhnya dapat memenuhi syarat kapasitas, adalah tergantung pada kehendak dari pada konstitusi masing-masing. sebagaimana konstitusi negara bahwa penyelenggaraan pemilihan umum yang langsung, umum, bebas, rahasia, jujur, dan adil maka

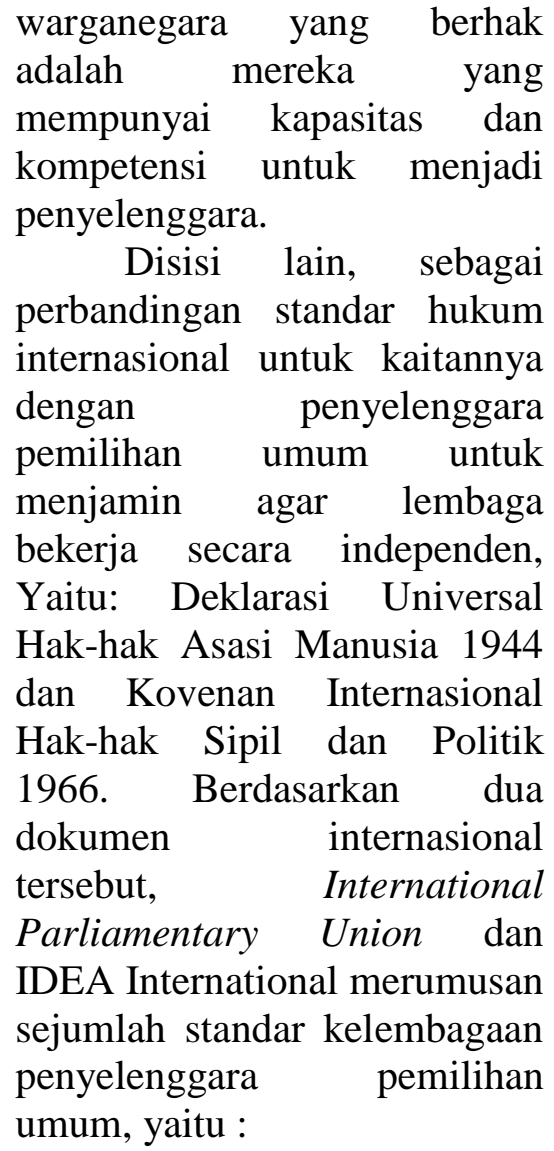

Pertama, Independensi penyelenggara pemilu merupakan persoalan penting, karena penyelenggara pemilu membuat dan melaksanakan keputusan yang dapat mempengaruhi hasil pemilihan umum. Oleh karena itu, lembaga tersebut harus bekerja dalam kerangka waktu cukup, memiliki sumberdaya mumpuni, dan tersedia dana memadai.

Kedua, Undang-undang pemilihan umum harus mengatur ukuran, komposisi, dan masa kerja anggota lembaga penyelenggara pemilu. Juga mengatur hubungan antara lembaga penyelenggara pemilu pusat dan lembaga-lembaga pemilu tingkat yang lebih rendah, serta hubungan antara semua lembaga pemilu dengan 
lembaga eksekutif. Undangundang harus membuat ketentuan tentang mekanisme untuk memproses, memutuskan, dan menangani keluhan dalam pemilu secara tepat waktu.

$$
\text { Sedangkan standar }
$$

kompetensi anggota di dalam kelembagaan adalah warganegara yang memiliki kompetensi, yang diberikan tugas dan fungsi sehingga penyelenggaraan pemilihan umum dapat menjawab amanah konstitusi, terhadap lembaga penyelenggara pemilihan umum yang tetap dan mandiri.

Maka,

ukuran

kompetensi sebagai penyelenggara pemilu paling tidak adalah

pertama, adanya

kejelasan undang undang yang mengatur mengenai hubungan kewenangan tugas penyelenggara di setiap tingkatan struktur, baik vertical maupun secara horizontal dengan lembaga lainnya.

\begin{tabular}{lr}
\multicolumn{1}{c}{ Kedua, } & adanya \\
kualifikasi & anggota \\
penyelenggara & pemilihan \\
umum yang professional dalam & \\
bidang keilmuan dan \\
pengalaman.
\end{tabular}

Ketiga, independensi bahwa penyelenggara tidak terpengarus dari pihak manapun baik secara politik maupun secara sosial, namun hanya tunduk pada suatu ketentuan hukum.

keempat, adanya mekanisme rekrutmenyang ketat, transparan, termasuk kesehatan, keilmuan (standak akademik), pengalaman, dan kredibilitas

\section{PEMILIHAN UMUM DI INDONESIA}

Komisi pemilihan umum sebagai sentral utama yang menyelenggarakan pemilihan umum, yang dapat saja membentuk lembaga lain guna menjadi bagian didalam pelaksanaan pemilihan umum. Dari hal tersebut, maka seharusnya terkait dengan tugas dan kewenangan yang diberikan kepada komisi pemilihan umum harus termaktub di dalam undang undang penyelenggara pemilihan umum dan undang undang lainnya. jika, berdasar pada konstitusi dimana lembaga komisi pemilihan umum merupakan lembaga yang menyelenggarakan pemilihan umum. maka, komisi pemilihan umum dapat membentuk adanya badan pengawas terhadap penyelenggaraan pemilihan umum.

Terkait lembaga yang melakukan pengawasan terhadap penyelenggaraan pemilihan umum, idelanya adalah dilaksanakan oleh lembaga komisi pemilihan umum. tentu dengan mekanisme dan peraturannya dapat dibuat oleh komisi pemilihan umum sebagai bagian dari penyelenggaraan pemilihan umum. Mengenai kompetensi yang diimiliki oleh badan pengawas tersebut juga ditentukan oleh komisi pemilihan umum. dengan ketentuan bahwa orang -orang yang terlibat di dalam 
pengawasan tersebut adalah mereka yang memang memiliki kompetensi, kredibilitas, dan akuntabilitas yang diuji secara pengalaman dari institusi yang bekerja pada tugas-tugas yudikatif.

Komisi pemilihan umum merupakan lembaga yang dibentuk secara konstitusi dan bekerja berdasarkan konstitusi dengan asas-asa yang sesuai dengan konstitusi pula. Maka, komisi pemilihan umum perlu melakukan penataan hukum yang tidak bertentangan dengan nilai konstitusi, dan unsur unsur sebagai negara hukum. Bahwa jika komisi pemilihan umum dalam pelaksanaan fungsi membuat peraturan itu dilengkapi dengan sistem hukum yang memadai, maka dapat dipastikan pelaksanaan tidak akan banyak menuai pesoalan tekhusus dari pada adanya dasar hukum yang dibuat oleh komisi pemilihan umum sesuai dengan ketentuan yang berlaku.

Di

dalam penyelenggaraan pemilihan umum begitu sangat kompleks, mulai dari perencanan, penyusunan regulasi, hingga pada hubungan kerjasaman atau koordinasi dengan pihakpihak yang berkompeten, pihak yang profesional, kesemua itu pelaksanaannya harus ada standar hukum. Sebagaimana negara Indonesia sebagai negara hukum, maka tentunya penyelenggaraan pemilihan umum harus berdasarkan hukum.

Dengan demikian pada aspek palaksanaan fungsi anggota KPU terkhusus pada pembuatan regulasi sebagai turunan terhadap suatu perundang undangan maka tentunya akan dapat dipastikan bahwa yang mampu melakukan tugas pembuatan peraturan perundang undangan adalah mereka yang memiliki kompetensi dan keahlian dibidang pembuatan peraturan perundang undangan tersebut. Sehingga anggota KPU tentunya adalah mereka yang salah satu tugasnya mampu melaksanakan tugas pembuatan peraturan pelaksana daru suatu undang undang. Pada intinya bahwa peneyelenggaraan pemilihan umum yang kompleks, maka penyelenggaranya harus professional.

Perlunya standar penataan hukum sebagai standar pemilihan umum yang demokratis dan berdasar pada asas-asa pemilihan umum, sebagaimana di katakan oleh Guy S Goodwin-Gil bahwa :

"Pemilu jujur dan adil (free and fair elections) dapat dicapai apabila tersedia perangkat hukum yang mengatur semua proses pelaksanaan pemilu; sekaligus mampu melindungi para penyelenggara, peserta, kandidat, pemilih, pemantau, dan warga negara pada umumnya dari ketakutan, intimidasi, kekerasan, penyuapan, penipuan, dan berbagai praktik curang lainnya yang akan mempengaruhi hasil 
pemilu. Oleh karena itu, pemilu yang jujur dan adil membutuhkan peraturan perundangan pemilu beserta aparat yang bertugas menegakkan peraturan perundangan Pemilu stersebut"

Jika dilihat dari konstitusi maka standar pemilihan umum sebagaimana dalan Pasal 22E terdiri 6 komponen standar umum, yakni:

1. Komponen asas, yaitu langsung, umum, bebas, rahasia, jujur, dan adil.

2. Komponen waktunya penyelenggaraan pemilihan umum adalah setiap lima tahun sekali.

3. Komponen tujuan penyelenggaraan pemiluhan umum adalah untuk pemilihan anggota Dewan Perwakilan Rakyat, Dewan Perwakilan Daerah, Presiden dan Wakil Presiden dan Dewan Perwakilan Rakyat Daerah.

4. Komponen peserta pemilihan umum, ada dua yakni pertama, untuk memilih anggota Dewan Perwakilan Rakyat dan anggota Dewan Perwakilan Rakyat Daerah adalah Partai Politik. kedua, untuk pemilihan umum anggota Dewan Perwakilan Daerah adalah perseorangan.

5. Komponen penyelenggara pemilihan umum, adalah komisi pemilihan umum.

6. Komponen sifat penyelenggara pemilihan umum, adalah bersifat nasional, tetap, dan mandiri.

Pelaksanaan pemilihan umum mengacu pada komponen standar sebagaimana dalam konstitusi. sedangkan komponen lain sebagai turunan adalah adalah beberapa undang undang yang terkait dengan penyelenggaraan pemilihan umum. Dengan demikian, setiap peraturan perundang undang yang tekait dengan penyelenggaraan pemilihan umum adalah berdasar pada asas, waku, penyelenggara, tujuan penyelenggaraaan, peserta pemilihan umum, penyelenggara pemilihan umum, dan sifat penyelenggara pemilhan umum.

\section{KESIMPULAN DAN SARAN}

Standar hukum internasional menghendaki adanya peraturan hukum penyelenggara pemilihan umum dengan ketentun adanya keterlibatan masyarakat (warganegara) yang secara individu dalam pemilihan umum. Sedangkan ketentuan hukum penyelenggara pemilihan umum di Indonesia tidak memiliki pengaruh signifikan terhadap hukum internasional sebab ketentuan penyelenggara pemilihan umum adalah memiliki kualitas profesionalitas, akuntabilitas, kredibilitas, dan professional dengan berdasar pada asas langsung, umum, bebas, rahasia, jujur, dan adil. 
dengan ketentuan sebagai lembaga yang independen, mandiri dan tetap.

Disarankan agar ketentuan hukum penyelenggara pemilihan memasukkan unsur-unsur profesionalitas, unsur akuntabilitas, unsur integritas dan unsur kredibilitas dalam peraturan perundang undangan.

\section{DAFTAR PUSTAKA}

Muchlis Hamdi, 2007 "State Auxiliary Bodies di Beberapa Negara", Disampaikan dalam dialog hukum dan non hukum "Penataan State Auxiliary Bodies dalam Sistem Ketatanegaraan"

Departemen Hukum dan HAM RI, Badan Pembinaan Hukum Nasional bekerjasama dengan Fakultas Hukum Universitas Airlangga, Surabaya 26-29 Juni

P Laslett And J Fishkin (ed). 1979. philosophy. politics and society. fifth series. new haven: yale university press.

Taylor, 1996. "election and politics in southeast asia," dalam rh taylor, ed, the politics of election in southeast asia, canbridge: woodrow wilson center press and canbrige university pres.,

Didik Sukriono. Menggagas Sistem Pemilihan Umum Di Indonesia. Jurnal Konstitusi. Vol. Ii. No. 1. Juni 2009. Jakarta. Hal.12

Didik Supriyanto, Menjaga Independensi

Penyelenggara Pemilu, Perludem, 2007, hlm. IV.

idea, standar-standar iternasional pemilihan umum: pedoman peninjauan

kembali kerangka hukum pemilu. Idea. Jakarta. 2002. Hal. 39-47.

St. Ulfah; Manuputty, Alma; Noor, SM; Wahid, AM Yumus. "Strict Liability Principle in Environmental Legal System." JL Pol'y \& Globalization 71 (2018): 100.

Salam, Abd. "Kedudukan Fungsi Peraturan Daerah (PERDA) sebagai Bagian Dari Hukum Nasional." Pleno Jure 4.5 (2015): 1-12.

Rahman, Sufirman, La Ode Husen, and Petrus Paulus Ell. "The Usage of Noken as an Alternative of the Ballot Box Replacement in the Middle Papua Mountain Area." JL Pol'y \& Globalization 60 (2017): 81.

\section{UUD NRI 1945}

Undang Undang No.11 Tahun 2011 tentang Penyelenggara pemilihan umum.

Deklarasi Dunia tentang Hak asasi manusia Tahun 1948 oleh (PBB) Deklarasi Dunia tentang Hak asasi manusia Tahun 1948 oleh (PBB)

Konvensi tentang Penghapusan Semua Bentuk Diskriminasi Terhadap Wanita tahun 1979

Perjanjian Internasional tentang Hakhak Sipil dan Hak-hak Politik Tahun 1966 (PBB)

Sidang Umum PBB, A/RES/46/137 tanggal 17 Desember 1991 tentang Peningkatan Keefektifan Prinsip Pemilu Berkala dan Murni (Laporan-laporan Sekjen, resolusi-resolusi

Sidang Umum, resolusi-resolusi ECOSOC, laporan-laporan dalam Komite HAM Dll 
Perjanjian Internasional tentang Hakhak Sipil dan Hak-hak Politik Tahun 1966 (PBB)

Konvensi tentang Hak-hak Politik Wanita tahun 1952 (PBB)

Deklarasi Parlemen Internasional Tentang Kriteria Untuk Pemilihan yang Bebas dan Adil Tahun 1994

Anonym. Sumber

http://www.rumahpemilu.or g/in/read/65/Mengapa-

Perlu-Standar-

Internasional-Pemilu

diakses 23 mei 2014

Penyelengara 